Issue no. $27 / 2018$

\title{
MIGRATION PATTERNS OF UNIVERSITY SPIN-OFFS: CASE STUDY OF REGION TWENTE, A NON-CORE REGION IN THE NETHERLANDS
}

\author{
Jacques Bazen \\ School of Business, Building and Technology, \\ Saxion University of Applied Sciences, Enschede, NL \\ j.c.bazen@saxion.nl
}

DOI:10.24193/OJMNE.2018.27.01

\begin{abstract}
This paper is a case study about location and migration patterns of university spin-offs. In this case study 1179 spin-offs of the University of Twente in the eastern part of The Netherlands have been identified and classified according to the definition of Pirnay et al. (2003) into four different types. These spin-offs have been longitudinally tracked throughout their existence, so that developments and migration patterns can be observed. There are interesting differences between different types of spin-offs in terms of their location: The spin-offs that received more explicit support from the university (for example in terms of coaching, providing of finance, IP protection, introduction into networks etc.) are more likely to stay in the region Twente, compared to the spinoffs of which the entrepreneur only got some implicit support (for example a general entrepreneurship course or maybe got in touch with inspiring entrepreneurs from existing spin-offs). Another issue explored in this paper is the often mentioned "brain drain" of spin-offs from non-core regions, as an analogy of brain drain of higher educated people from such regions. Even though firms in general are less mobile than people, it is indeed striking to see differences in firm growth in number of employees, among companies which migrate from economic non-core regions to core-regions. Migrating spin-offs from Twente to large agglomerations in The Netherlands grow on average three times faster than companies that stay in the region of origin. Still, knowledge intensive patent-based spin-offs tend to stay close to the parent university, likely because of knowledge spill-overs from the university. These findings can help university administrators to increase effectiveness of their entrepreneurship support systems, by investing in supporting different types of spin-offs with access to regional business networks, to help also less visible and lower tech spin-offs to root more in the region.
\end{abstract}

Keywords: spin-offs, university, entrepreneurship. 
Issue no. $27 / 2018$

\section{Introduction}

The last decade there is a growing interest among researchers about the role that regional contexts play in stimulating or discouraging entrepreneurship, as well as the effect of entrepreneurship on regions, especially on knowledge intensive university spin-offs. This is however a very broad and fragmented subject and several directions of research into this subject can be identified, since the field is still considered "to be moving towards a more theory-driven research" (Rothaermel, Agung, \& Jiang, 2007). Three directions of research related to regional influences on entrepreneurship are mentioned here: One direction of research is about the influence of (regional) culture and business/entrepreneurship education in influencing entrepreneurial intention, in order to increase the number of start-ups or at least the percentage of students/graduates interested in starting their own business (See for example: Carsrud \& Brannback, 2011; Krueger, Reilly, \& Carsrud, 2000; Luthje \& Franke, 2003; O'Shea, Allen, Chevalier, \& Roche, 2005; Shinnar, Giacomin, \& Janssen, 2012). This type of research has often been plagued by low predictability scores for entrepreneurial intention, as well as an underdevelopment in theory in this field (Krueger, 2009). Empirical studies among successful entrepreneurs show that they are usually not exactly linear thinkers who have a clear plan in advance (Sarasvathy, 2001; Sarasvathy \& Venkataraman, 2011). Therefore, policies aimed to increase entrepreneurship among students or graduates via influencing entrepreneurial intention have often yielded limited results (Krueger, 2009), or otherwise said, the link between intention and action is not (yet) well understood (Bird \& Schjoedt, 2009). A second direction of research into supporting entrepreneurship is about the institutional support context, meaning here the effects of different facilities from either regional governments or universities in supporting entrepreneurship, ranging from coaching/mentoring to business incubation and financial support (See for example: Benneworth \& Charles, 2005; Duma, 2014; Etzkowitz, Webster, Gebhardt, \& Terra, 2000; Koopman, 2013). Etzkowitz and Leydesdorff (2000) speak of a "third mission" for universities, the mission to valorise new knowledge, next to the traditional missions of education and research. The successful application of this third mission of universities involves a central place for entrepreneurship within the university, this third mission idea has 
been one of the influential ideas leading to increasing numbers of regional entrepreneurship support ecosystems (Arbo \& Benneworth, 2007; Goddard \& Chatterton, 2003; Parmentola \& Ferretti, 2018). As a third direction of entrepreneurship research, a growing number of publications is dedicated to the effects of entrepreneurship on the regional of knowledge intensive spin-offs from universities and/or research institutes. Armstrong (2001) observed a strong tendency of clustering of knowledge intensive spin-offs in what he calls "totemic sites of the new economy", a relatively small number of places with a lot of attraction for these types of business. This makes it difficult for universities in more peripheral regions without a well-developed support infrastructure for knowledge intensive enterprises to understand and measure what is exactly their real effect (Benneworth \& Charles, 2005; Harrison \& Leitch, 2010), since knowledge intensive start-ups might move away from the region in which they originated, or students and/or recent graduates from universities in such regions may decide to start their business in another region altogether. Therefore, looking at the costs and benefits of entrepreneurial support programs, one might for more peripheral regions very well come to the conclusions that the costs of such programs may outweigh the benefits (Hughes, 2010). To take also effects of such programs, on other regions into account is a virtually insurmountable methodological problem, however it is possible to track start-ups after their official establishment, and it is possible to see if they are indeed moving out on a large scale or not. This paper consists of a case study of university spin-offs related to the University of Twente, located in the eastern part of The Netherlands (see figure 2). A related study on spinoff location, and migration intention (not actual migration) has been done for Saxion University of Applied Sciences, another higher education institution in the same region (Van der Meer, Van der Meer, \& Bijleveld, 2010). The goal of this paper therefore is to add to the debate of effectiveness of entrepreneurship education by identifying what happens with startups after they have been established, in terms of locational pattern and company growth (in terms of company size). A longitudinal study such as this one may help to add knowledge to the behaviour of university start-ups in more peripheral regions of Western Europe. 
Issue no. $27 / 2018$

\section{Theoretical framework}

To provide clarity, it is necessary to define and discuss a number of concepts and theories related to the location patterns of university spin-offs. First of all it is needed to define the concept of university spin-off, because there are a lot of different definitions around for university related start-ups, ranging from Robert's (1991) very wide definition, which includes all companies started by staff and (former) students of a university, to a narrow definition by Shane (2004) about spinoffs being established to commercialize intellectual property that was created based on research results by a university. These different definitions obviously make comparisons between different studies a complicated exercise. Pirnay et al. (2003) therefore, formulated a framework with four types of spinoffs (see figure 1), which is largely used in this study, with the additional suggestion of

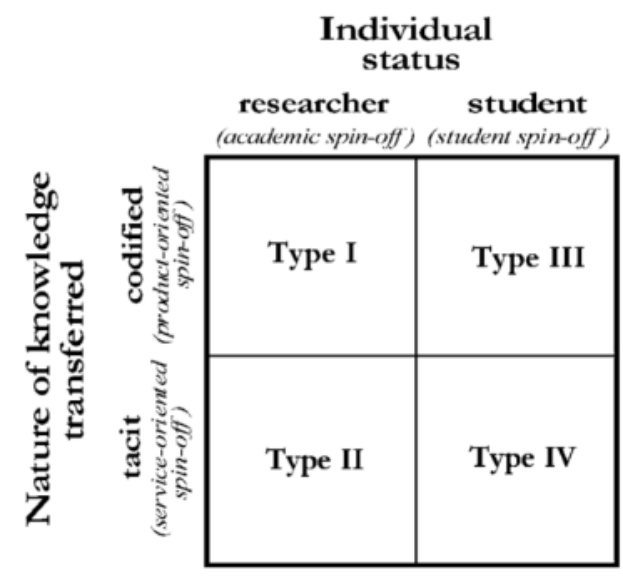

Figure 1: A typology of University Spin-offs (Pirnay, Surlemont, \& Nlemvo, 2003) Cocorullo (2017) to distinguish between more high tech and low tech spin-offs. The first spin-off type (Type I) that Pirnay et al. identify closely resembles Shane's definition of a university spin-off and consists of the commercialization of new research technology, usually protected by using patents. In this study, patent-based spin-offs will also be called Type I spin-offs. Type II spin-offs are based on commercialization of research results, but without patents. Most of these spin-offs are service based and profit from the available tacit knowledge within the university. In this study, these research-based spin-offs are also classified as Type II spin-offs. The spin-off Types III and IV of Pirnay et al. are student spin-offs, of which type III are the more explicitly supported ones and type IV the more implicitly supported ones. In the before mentioned study of Cocorullo, type I and II are usually the more high-tech spin-offs and type III and IV usually more low-tech spin-offs. Sometimes the type IV companies are even called "lifestyle companies" (Timmons \& Spinelli, 2008) or an "alternative to the paid labour market" (Harrison \& Leitch, 2010) to distinguish them from the more research based 
companies. The majority of the spin-offs of this Type III and IV remain small and several authors therefore do not consider Type III and IV to be true spin-offs (See for several discussions on spin-off definitions for example Djokovic \& Souitaris, 2008; Mustar et al., 2006; Pirnay et al., 2003; Roberts, 1991). On the other hand, there is in the Dutch region Twente (the object of this study), and especially at the University of Twente already a long experience with entrepreneurship education and support for all its students (Bazen \& Bijleveld, 2012; Benneworth \& Hospers, 2007b; Pirnay et al., 2003; Van der Sijde \& Van Tilburg, 2000; Van Tilburg \& Van der Sijde, 1998), which is a good reason to still include Type III and IV spin-offs in this study. Since there can be quite a substantial time-lag between scientific research and the commercial application of it (Müller, 2010), the definition of spin-off in this study includes the businesses that have been started up to 5 years after the founder left the university either as staff member or graduated as student.

The question why in some regions more spin-offs are generated than in other regions is often explained by the university policies regarding entrepreneurship (Di Gregorio \& Shane, 2003) as well as the so-called knowledge spill-over theory. This theory explains that people are more likely to start a business if they have access to knowledge spill-overs from university research and can turn those into profit bearing opportunities (Acs, Braunerhjelm, Audretsch, \& Carlsson, 2009; Audretsch \& Lehmann, 2017; Romer, 1990) and it also explains why such spin-offs are found geographically in close proximity of the university that they originate from (Roberts, 1991). The knowledge spill-over theory has been criticized and nuanced by Down $(2010$, pp. 153, 157), who suggested that even though knowledge spillovers may exist, it is also clear that small businesses can get their knowledge from whenever where and not necessarily from the university that they are located next to. Even though this is a plausible nuance of the knowledge spill-over theory, the theory still explains the location patterns of knowledge intensive spin-off companies and is therefore used as explanation in this study as well. Still, when taking knowledge spill-overs in mind, it remains to be seen if more peripheral regions like Twente, produce enough knowledge spill-overs to remain attractive for university spin-offs in the long run. This is all the more important, because of the ongoing process of globalization and the need for developed countries to specialize in knowledge intensive activities in order to stay competitive with the rest of the world (Maskell 
Issue no. $27 / 2018$

\& Malmberg, 1999). Audretsch and Lehmann (2005) studied firm birth rates in Germany and observed that the highest firm birth rates coincided with the most densely populated regions, with a high population growth, the lowest unemployment rates, the highest amounts of skilled workers and a strong presence of small businesses. The fact that there still seemed to be ample room for starting new businesses can be explained by the abundance of knowledge spill-overs, which occur from among others university research (Audretsch \& Lehmann, 2005, 2017). The existence of many knowledge spill-overs can lead to the formation of business clusters (Porter, 1990), which can offer strong reasons for companies to locate themselves in a certain region (Wever \& Stam, 1999). In addition, the availability of a creative workforce has been mentioned as important factor to increase the attractiveness of those kind of regions even more (Florida, 2002, 2008). The problem of less densely populated, more rural and peripheral regions is that the knowledge spill-overs and available business clusters, if any at all, tend to be weaker than in core regions (See for example Bode (2004) for a case study about German regions). Harrison and Leitch (2010) conclude that in the peripheral region that they studied, IP-based spin-offs (The type I spin-offs) usually stay small, and are just there exploiting one or more patents, without much desire as well as potential to grow. On the other hand, Benneworth and Charles (2005) remark that it has (so far) never been proven that the activities of spin-offs hurt in any way the regional economy, although they may be operating globally instead of regionally. This could however, also mean that such companies would find better opportunities for growth elsewhere and would probably be interested to move out from such regions.

\section{Peripheral regions in Western Europe: Case study of Twente}

The concept of core and periphery originates from the economic dependency theory, formulated at the end of the 1940s by Singer and Prebisch, and was developed by Wallerstein (1974) into the broader world system theory, which stated that unequal economic exchange between core and periphery works to the benefit of the core, and would lead to amassing wealth (and knowledge) there. Therefore, the periphery is needed to support the core, but the unequal exchange causes the periphery to remain relatively underdeveloped. A special case of peripheral regions in Western Europe are the so-called industrial restructuring regions, 
formerly heavily dependent on one or two types of (usually heavy) industry (Hospers, 2015). Competition with low-wage countries has often led to a strong decline in industrial production in such regions, especially in the regions without too many innovative industries. These regions are sometimes plagued by institutional lock-in (Grabher, 1993) which greatly hindered and in some cases still hinders access to global innovative investments and are at risk getting into a vicious circle of further disinvestment and restructuring (Benneworth \& Hospers, 2007a; Tödtling \& Trippl, 2005). National governments of Western European countries began to support the development of entrepreneurship, to generate new élan in the regions and as one of the ways to avoid Grabher's institutional lock-in (Benneworth \& Hospers, 2007b; Hospers, 2015). When zooming in on such regions a bit more and looking at the available literature on innovation policies in post-industrial regions, it becomes clear that a lot of studies are available on this subject for different regions. Baumgartner, Pütz, and Seidl (2013) provide an extensive overview on the available literature on this subject. To mention just a few interesting findings of studies of specific regions related to the goal of this study: Specific challenges of regional innovation systems in the North-East of England in bridging the gap between university and business (Goddard, Robertson, \& Vallance, 2012), the importance of the science parks in the development of university spin-offs in several Spanish regions (Fernández-Alles, Camelo-Ordaz, \& Franco-Leal, 2015), the vibrancy in terms of spin-off activity in Western-Ireland because of local freedom to deal with IP, compared to a more centralized and hierarchical situation in Spain, requiring strong entrepreneurial leadership within universities there (Guerrero, Urbano, Cunningham, \& Organ, 2014), the importance of not to blindly copy innovation policies from other regions in a study about the applicability of the triple helix model in Wales (Pugh, 2017), how the limited market, absence of investors and discouraging behaviour of universities can seriously hinder the development of spin-offs in Southern Italy (Parmentola \& Ferretti, 2018) and finally the importance of community development in a comparative study on 18 European peripheral regions by Terluin (2003). Such case studies can shed light on the reasons behind the observed migration patterns of university spin-offs.

As written before, the object of this study is the migration pattern of spin-offs in the region Twente in The Netherlands. The Twente region industrialized in the second half of the 
Issue no. $27 / 2018$

$19^{\text {th }}$ century and specialized in textile industry. Currently the region has around 625000 inhabitants, the largest city (and location of the University of Twente) in the region is Enschede. Due to globalization and the outsourcing of work places, the region has lost almost all companies operating in the textile production business. It falls outside the scope of this study to discuss the history of this region in great detail, but more on the emergence and development of the textile industry in Twente can be read in the work of Boot (1935). More detailed information on the collapse of the textile industry during the 1960s and 1970s, and the economic consequences for Twente can for example be found in Bazen and Bijleveld (2012). To deal with the economic problems, one of the measures was investment in knowledge intensive entrepreneurship. Twente was one of the regions in which the dominant university (University of Twente) focused early on (since the beginning of the 1980s), on teaching entrepreneurship and valorisation of innovation, in order to help reinforce the economic structure of the region (Benneworth \& Hospers, 2007a, 2007b; Lazzeretti \& Tavoletti, 2005; Van der Sijde, Vogelaar, Hoogeveen, Ligtenberg, \& Van Velzen, 2002). Clarysse, Wright, Lockett, Van de Velde, and Vohora (2005) identified the entrepreneurial mission and subsequent entrepreneurial spirit of the University of Twente as the most important trigger for the establishment of its spin-offs. The key idea of the regional government and the university of Twente was, just like in the previously mentioned studies on other regions in Europe, to support high tech, knowledge intensive entrepreneurship, in order to support high growth firms, that would in turn create high qualified jobs for the region (Van der Sijde \& Van Tilburg, 2000), allowing alumni to find suitable workplaces, thus contributing to regional development. A survey however, among graduates of universities from several more peripheral border regions in Western Europe (including graduates of the University of Twente) indicated that around $75 \%$ of all graduates are leaving these regions (Institute for Work and Technology Westfälische Hochschule, 2014). This is a high percentage of "lost" human capital for these border regions. Still, when alumni do migrate elsewhere, it doesn't mean that all is lost: There is evidence that alumni who were born or studied in a certain region have more ties with that region and therefore have a larger chance to migrate back, than people who are completely unfamiliar with that region (David \& Coenen, 2014). The question is, if this pattern of alumni migration also applies for the 
university spin-offs. In case that it does, peripheral regions like Twente can be birthplaces and "incubator regions" for spin-offs, but as soon as they are growing (in terms of job places and/or turnover) they will leave the region in search for better opportunities, thereby supporting the already existing core-periphery structure.

The subject of firm migration has been somewhat under researched, as there are numerous studies on the establishment of enterprises, on growth as well as closure, but rather few on relocation of firms. It is evident that for well-established knowledge intensive university spin-offs it is not very convenient to migrate, as they are usually well connected in a network with their parent university, as well as the fact that moving the business is a costly operation (Atzema, Lambooy, Rietbergen, \& Wever, 2002). Still, companies move, and it is interesting to observe patterns. One of the reasons that there has been relatively little research on firm relocation is that there are no clear theoretical concepts found behind the company migration. Mäkelä and Maula (2005) found some evidence that companies with venture capital investment tend to move towards the country in which the venture capitalist investor is located. Although not statistically significant because of the low numbers, such a pattern might be also present among venture capital backed companies in Florida in the USA (Plant, 2007). There is however no widely established theory for company migration, which may be one of the reasons why this field is somewhat neglected (de Bok, 2004; Van Wissen \& Schutjens, 2005). Nonetheless, firm relocations are certainly of interest, as it is a 'showcase of entrepreneurial decision making' regarding the place from which it is best to do business (Pellenbarg, 2005). In the same paper, Pellenbarg identifies the main and secondary motives for companies to relocate. He found that "lack of space for growth", "business economic reasons" (meaning among others a search for lower wages, more qualified staff, proximity to investors and customers) and "accessibility" were the most important motives for moving. There is a clear distinction between company size and motives to move: Small businesses usually move because of lack of space, whereas large settled (industrial) firms tend to relocate more because of "business economic reasons" (Pellenbarg, 2005; Van Dijk \& Pellenbarg, 2000). It must be noted that these firm relocations are about all firms in The Netherlands, not just about university spin-offs. Van Wissen and Schutjens (2005) studied migration patterns of companies in The Netherlands extensively and concluded that Dutch 
Issue no. $27 / 2018$

companies are in general rather sedentary (not surprising given the small size of the country) and that firm relocations, if they happen, are generally on small distances. A comparative study within 21 countries on firm relocations by Brouwer, Mariotti, and Van Ommeren (2004) showed that most company relocations in Europe were the consequences of mergers and takeovers, but also here, the data is about all companies and not specifically about university spin-offs. Still these observations are valuable to compare with the migration patterns of the university spin-off companies from the region Twente.

\section{Methodology \& results}

This paper consists of the results of a longitudinal study into all - identified university spin-off companies of the University of Twente. All companies have been tracked throughout their existence and put in a yearly updated database, containing the following variables:

1. Founding year

2. Location of origin

3. Location (yearly updated)

4. Number of employees (yearly updated)

5. Main activity type (Based on NACE/ISIC classification)

6. Spin-off type (I to IV, based on Pirnay et al. (2003)).

The database with university spin-offs (all 4 types) consists of 1179 companies in total, of which 822 are reported to be active in 2017 by the Chamber of Commerce. The oldest spin-off in the database has been established in 1973 (The University of Twente is a young university dating back only to 1961), and the data has been updated until 2017. The data about the spin-offs has been partly obtained Business \& Science Park organization Novel-T in Enschede, from business developers, spin-off data from the University of Twente and finally also a Linked-in search with search terms like "founder, CEO, entrepreneur" etc. and "studied/worked at the University of Twente". In all cases only companies which are founded less than five years after the entrepreneur was leaving the University of Twente have been taken into consideration. All companies found have been checked by consulting the trade register of the Chamber of Commerce, in which all legally active companies are 
Issue no. $27 / 2018$

included. The entry in the trade register also includes the number of workplaces of each company, either based on the company's yearly account statement, or an estimate by the Chamber of Commerce. In terms of reliability, Pellenbarg (2005) argues that it is hard to track company movements, and employment data in The Netherlands, due to unreliable company data in the trade register of the Chambers of Commerce. After 1998 the situation has certainly improved, but given this unreliable source, no employment data before 1998 will be taken into the analysis. There are no cases in the database of companies moving abroad. This doesn't mean that all University of Twente spin-off companies stay in the Netherlands, but rather that these companies usually get de-registered from the Dutch trade register and therefore appear to cease to exist, although they in fact only disappear from the data source. It is therefore with the trade register data set not possible to find out how many spin-offs moved abroad. It is assumed that this number is relatively low.

All spin-offs have been grouped into 4 types, based on Pirnay et al. (2003).

- Type I consists of knowledge intensive patent-based spin-offs (usually started by a staff member of the university for the valorisation of research findings).

- Type II are spin-offs which are based on the results of research but without patent (Pirnay et al. call this type of spin-offs the ones which are based on tacit knowledge).

- Type III are student spin-offs that have gotten in one way or another concrete support from the entrepreneurial ecosystem, such as advice or were part of the business incubator. Often these spin-offs have gotten support from the University of Twente TOP-support program "Tijdelijke Ondernemers Plaatsen" (Temporary Entrepreneurship Scheme). See for more details Van der Sijde et al. (2002) and Benneworth and Charles (2005).

- Type IV are all other spin-offs of both staff members and students which may have gotten some form of entrepreneurship support in the form of entrepreneurial courses in the university or were inspired by other spin-offs.

In terms of division of the spin-offs into four categories, the following picture (table 1 $\& 2$ ) emerges in terms of the total number of identified spin-offs and the active number of spin-offs in 2017, as well as some data about the total amount of workplaces in these spinoffs and the average number of workplaces per spin-off. 
Table 1: Number of different spin-off types (until 2017) of the University of Twente

\begin{tabular}{|l|l|l|}
\hline Spin-off types & $\begin{array}{l}\text { Total number of identified } \\
\text { spin-offs }\end{array}$ & $\begin{array}{l}\text { Active number of spin-offs } \\
\text { (in 2017) }\end{array}$ \\
\hline Type I & 37 & 31 \\
\hline Type II & 150 & 104 \\
\hline Type III & 477 & 302 \\
\hline Type IV & 515 & 385 \\
\hline Total & 1179 & 822 \\
\hline
\end{tabular}

Table 2: Employment in the different spin-off types of the University of Twente in 2017

\begin{tabular}{|l|l|l|l|}
\hline Spin-off types & $\begin{array}{l}\text { Active number of } \\
\text { spin-offs }\end{array}$ & $\begin{array}{l}\text { Total amount of } \\
\text { workplaces }\end{array}$ & $\begin{array}{l}\text { Average number of } \\
\text { workplaces }\end{array}$ \\
\hline Type I & 31 & 233 & 7.5 \\
\hline Type II & 104 & 676 & 6.6 \\
\hline Type III & 302 & 2985 & 9.9 \\
\hline Type IV & 385 & 3941 & 10.5 \\
\hline Total & 822 & 8078 & 9.0 \\
\hline
\end{tabular}

In terms of the average number of jobs per spin-off in table 2, it must be noted that this figure is highly skewed, with $54 \%$ of the total active spin-offs being sole proprietors and the 15 largest spin-offs being responsible for providing approximately half the amount of the jobs and none of these 15 being Type I or Type II spin-offs. These findings are partly similar to the findings of Timmons and Spinelli (2008) and Harrison and Leitch (2010), when talking about the on average small size of most of the Type III and IV spin-offs. It cannot be seen (at least not from the number of work places) if the Type I and Type II spin-offs are faster growing and generate more impact in the regional economy as Timmons and Spinelli predict. The observation about the low number of workplaces of the Type I and II spin-offs seem to 
Issue no. $27 / 2018$

fit more with the ideas of Hughes (2010), Harrison and Leitch (2010) as well as Down (2010), about the limited impact of university spin-offs in the regional innovation system. Still, from this data it cannot be said for certain that these companies only play a limited role, because even small high-tech companies could play a crucial role in different supply chains as technology provider. There is however little evidence from these numbers, to conclude that the ambitious goals for regional development of Twente, as described by Van Tilburg and Van der Sijde (1998), with the help of creation of high tech university spin-offs have been reached by now.

Now, after discussing some basic information of the different types of spin-offs, it is possible to focus on the actual spin-off migration patterns. The data about the spin-offs in table 1 and 2 consists of the aggregate data of all spin-offs. When looking at the location of the different spin-offs in table 3,64\% of the spin-offs is in Enschede or the rest of the region Twente, consistent with what could be expected from the knowledge spill-over theory. This is specifically the case for the type I spin-offs. The other categories consist of all other places within the region Twente outside of the city of Enschede, the top-5 largest agglomerations in The Netherlands (Amsterdam, Rotterdam, The Hague, Utrecht, Eindhoven), and a rest category of all other regions in The Netherlands.

Table 3: Locations of spin-off companies of the University of Twente (2017)

\begin{tabular}{|l|l|l|l|l|l|l|l|l|l|l|}
\hline $\begin{array}{l}\text { Spin- } \\
\text { off } \\
\text { type }\end{array}$ & Total & Enschede & $\begin{array}{l}\text { Twente-region } \\
\text { (Excluding } \\
\text { Enschede) }\end{array}$ & $\begin{array}{l}\text { Other regions } \\
\text { (Excluding } \\
\text { Top 5 largest } \\
\text { cities) }\end{array}$ & $\begin{array}{l}\text { Top 5 largest } \\
\text { cities in } \\
\text { Netherlands }\end{array}$ \\
\hline Type I & 31 & $100 \%$ & 21 & $68 \%$ & 6 & $19 \%$ & 3 & $10 \%$ & 1 & $3 \%$ \\
\hline Type II & 104 & $100 \%$ & 65 & $63 \%$ & 12 & $11 \%$ & 21 & $20 \%$ & 6 & $6 \%$ \\
\hline $\begin{array}{l}\text { Type } \\
\text { III }\end{array}$ & 302 & $100 \%$ & 153 & $51 \%$ & 77 & $25 \%$ & 60 & $20 \%$ & 12 & $4 \%$ \\
\hline Type & 385 & $100 \%$ & 113 & $29 \%$ & 77 & $20 \%$ & 159 & $41 \%$ & 36 & $10 \%$ \\
\hline
\end{tabular}


Issue no. $27 / 2018$

\begin{tabular}{|l|l|l|l|l|l|l|l|l|l|l|}
\hline IV & & & & & & & & & & \\
\hline Total & 822 & $100 \%$ & 352 & $43 \%$ & 172 & $21 \%$ & 243 & $30 \%$ & 55 & $6 \%$ \\
\hline
\end{tabular}

The data in table 3 doesn't automatically imply that the $36 \%$ of spin-off companies located outside of the region Twente have all migrated from Twente or Enschede. On the contrary, most companies in the database are quite stable in terms of firm location, consistent with the conclusions of Van Wissen and Schutjens (2005). Most of the spin-offs belonging to the $36 \%$ located outside of the region have been established from their start outside of the region Twente. Still, there are several company movements registered in the spin-off research database. These company movements or firm migrations have been classified as intraregional or inter-regional movements. The regional level which is used to classify the company migrations is the EU NUTS-2 level (with the exception of Twente, a NUTS-3 region within the NUTS-2 region of Overijssel). Intra-regional migrations are firm migrations within the same NUTS-2 region, and inter-regional migrations means migration to a different NUTS-2 region (again with the exception of Twente).

When analysing the firm migrations present, 177 intra-regional migrations have been observed, and 156 inter-regional migrations. 62 of the inter-regional migrations were sole proprietors, compared to 56 of the intra-regional migrations. The average age of the spin-off at the time of the recorded inter-regional migration is 10 years, which means that most companies that move to a different region, do so after they have reached a more "mature" state. The average age of a spin-off at the time of the recorded intra-regional migration is 9 years, also outside the first "start-up" period in the company's lifecycle. For all specific company migrations the observations of Pellenbarg (2005) have to be taken in consideration: The used dataset of the Chamber of Commerce may be unreliable. What is more, a firm migration does not automatically mean a loss of workplaces in the region that the company moved out from. Sometimes it just represents an administrative move of the official company location (just the relocation of the company headquarters, while production remains where it was). Still in such cases, even though it means no or little job loss for the region of origin, it 
Issue no. $27 / 2018$

still shows a changing "centre of gravity" towards a new region for such a company. Table 4 shows the migration numbers of companies to and from the region Twente and Enschede.

Table 4a. Migration of Type I spin-offs

\begin{tabular}{|l|l|l|l|l|l|}
\hline Spin-off type I & $\begin{array}{l}\text { Established } \\
\text { in Enschede }\end{array}$ & $\begin{array}{l}\text { Established in } \\
\text { Twente region } \\
\text { (Excluding } \\
\text { Enschede) }\end{array}$ & $\begin{array}{l}\text { Established in } \\
\text { other regions }\end{array}$ & Total & $\begin{array}{l}\text { Net } \\
\text { migration } \\
\text { balance }\end{array}$ \\
\hline $\begin{array}{l}\text { Located in 2017 } \\
\text { in Enschede }\end{array}$ & 18 & 2 & 1 & 21 & 0 \\
\hline $\begin{array}{l}\text { Located in 2017 } \\
\text { in Twente region } \\
\text { (Excluding } \\
\text { Enschede) }\end{array}$ & 0 & 4 & 0 & 4 & -2 \\
\hline $\begin{array}{l}\text { Located in 2017 } \\
\text { in other regions }\end{array}$ & 3 & 0 & 3 & 6 & +2 \\
\hline Total & 21 & 6 & 4 & 31 & \\
\hline
\end{tabular}

Table 4b: Migration of Type II spin-offs

\begin{tabular}{|l|l|l|l|l|l|}
\hline Spin-off type II & $\begin{array}{l}\text { Established } \\
\text { in Enschede }\end{array}$ & $\begin{array}{l}\text { Established in } \\
\text { Twente region } \\
\text { (Excluding } \\
\text { Enschede) }\end{array}$ & $\begin{array}{l}\text { Established in } \\
\text { other regions }\end{array}$ & Total & $\begin{array}{l}\text { Net } \\
\text { migration } \\
\text { balance }\end{array}$ \\
\hline $\begin{array}{l}\text { In 2017 in } \\
\text { Enschede }\end{array}$ & 56 & 5 & 4 & 65 & -7 \\
\hline $\begin{array}{l}\text { In 2017 in } \\
\text { Twente region } \\
\text { Excluding } \\
\text { Enschede) }\end{array}$ & 6 & 6 & 0 & 12 & +1 \\
\hline In 2017 in other & 10 & 0 & 17 & 27 & +6 \\
\hline
\end{tabular}


Issue no. $27 / 2018$

\begin{tabular}{|l|l|l|l|l|l|}
\hline regions & & & & & \\
\hline Total & 72 & 11 & 21 & 104 & \\
\hline
\end{tabular}

Table 4c: Migration of Type III spin-offs

\begin{tabular}{|l|l|l|l|l|l|}
\hline Spin-off type III & $\begin{array}{l}\text { Established } \\
\text { in Enschede }\end{array}$ & $\begin{array}{l}\text { Established in } \\
\text { Twente region } \\
\text { (Excluding } \\
\text { Enschede) } \\
\text { other regions }\end{array}$ & $\begin{array}{l}\text { Established in } \\
\text { Total }\end{array}$ & $\begin{array}{l}\text { Net } \\
\text { migration } \\
\text { balance }\end{array}$ \\
\hline $\begin{array}{l}\text { In } 2017 \text { in } \\
\text { Enschede }\end{array}$ & 144 & 5 & 4 & 153 & -35 \\
\hline $\begin{array}{l}\text { In 2017 in } \\
\text { Twente region } \\
\text { (Excluding } \\
\text { Enschede) }\end{array}$ & 24 & 50 & 3 & 77 & +17 \\
\hline $\begin{array}{l}\text { In 2017 in other } \\
\text { regions }\end{array}$ & 20 & 5 & 47 & 72 & +18 \\
\hline Total & 188 & 60 & 54 & 302 & \\
\hline
\end{tabular}

Table 4d: Migration of Type IV spin-offs

\begin{tabular}{|l|l|l|l|l|l|}
\hline Spin-off type IV & $\begin{array}{l}\text { Established } \\
\text { in Enschede }\end{array}$ & $\begin{array}{l}\text { Established in } \\
\text { Twente region } \\
\text { (Excluding } \\
\text { Enschede) }\end{array}$ & $\begin{array}{l}\text { Established in } \\
\text { other regions }\end{array}$ & Total & $\begin{array}{l}\text { Net } \\
\text { migration } \\
\text { balance }\end{array}$ \\
\hline $\begin{array}{l}\text { In 2017 in } \\
\text { Enschede }\end{array}$ & 407 & 4 & 2 & 113 & -25 \\
\hline $\begin{array}{l}\text { In 2017 in } \\
\text { Twente region } \\
\text { (Excluding } \\
\text { Enschede) }\end{array}$ & 7 & 69 & 1 & 77 & -3 \\
\hline
\end{tabular}


Issue no. $27 / 2018$

\begin{tabular}{|l|l|l|l|l|l|}
\hline $\begin{array}{l}\text { In } 2017 \text { in other } \\
\text { regions }\end{array}$ & 24 & 7 & 164 & 195 & +28 \\
\hline Total & 138 & 80 & 167 & 385 & \\
\hline
\end{tabular}

Table $4 \mathrm{a}$ to $\mathrm{d}$ show the movement of spin-offs of all the 4 types between the different regions. It can be clearly seen that both Enschede and the rest of the region Twente have a negative net migration balance. When looking at the percentages of companies moving out of the region of origin or staying there (see table 6), it becomes clear that percentagewise the region Twente (including Enschede) has the strongest attraction for the knowledge intensive Type I and II spin-offs of the University of Twente. This seems to confirm the ideas of Roberts (1991), who postulated that knowledge intensive spin-offs would be located in close proximity to the parent university, in order to profit from knowledge spill-overs (Audretsch \& Lehmann, 2005). At the same time, for the spin-off Types III and IV, the attraction of relocating to either Enschede or other parts of the region Twente seem to be lower, which may be caused by their looser connection to knowledge available at the university, or lesser involvement in regional networks (especially for spin-off Type IV) (Cocorullo, 2017; Pirnay et al., 2003).

Table 5: Percentages of spin-offs staying and moving out from the regions of origin

\begin{tabular}{|l|l|l|l|l|}
\hline Spin-off type & $\begin{array}{l}\text { Established in } \\
\text { Enschede or } \\
\text { Twente region, } \\
\text { still located } \\
\text { there }\end{array}$ & $\begin{array}{l}\text { Established in } \\
\text { Enschede or } \\
\text { Twente region, } \\
\text { now outside the } \\
\text { region }\end{array}$ & $\begin{array}{l}\text { Established } \\
\text { outside } \\
\text { Enschede or } \\
\text { Twenteregion, } \\
\text { still located } \\
\text { there }\end{array}$ & $\begin{array}{l}\text { Established } \\
\text { outside Enschede } \\
\text { or Twenteregion, } \\
\text { now located in } \\
\text { Enschede or } \\
\text { Twente }\end{array}$ \\
\hline Type I & $89 \%$ & $11 \%$ & $75 \%$ & $25 \%$ \\
\hline Type II & $88 \%$ & $12 \%$ & $81 \%$ & $19 \%$ \\
\hline Type III & $90 \%$ & $10 \%$ & $87 \%$ & $13 \%$ \\
\hline Type IV & $86 \%$ & $14 \%$ & $98 \%$ & $2 \%$ \\
\hline
\end{tabular}


Issue no. $27 / 2018$

Another way of looking at the impact of spin-off migration is to look at the numbers of jobs involved. Pellenbarg (2005) found that "lack of space to expand" and "business economic reasons" were main drivers for company migration. Since this study does not consist of a survey or interviews among the University of Twente spin-offs to question them about their motives to relocate, there can be no conclusions on the motives itself. Still, Pellenbarg's findings suggest that companies that would move to core regions with better business opportunities, would grow faster than companies that stay in the Twente region. Company growth is a fuzzy term, and can be defined in different ways, for example in terms of turnover or number of employees. Since there is no data available in the research database about company turnover, and since the number of employees is known, number of employees is chosen as indicator for company growth. It must be noted that the employee numbers may be slightly inaccurate. In the case of some spin-offs, the number of employees in the Dutch trade register consists of an estimation of the Chamber of Commerce, instead of information from the yearly account statement of the company. Table 5 shows the development in number of job places in the companies that moved out of Twente, as well as the development of number of jobs in companies that stayed within the region Twente.

Table 6: Migration and company size

\begin{tabular}{|l|l|l|l|l|l|}
\hline $\begin{array}{l}\text { Average } \\
\text { company } \\
\text { size in } \\
\text { number of } \\
\text { workplaces }\end{array}$ & $\begin{array}{l}\text { Established } \\
\text { in } \\
\text { Enschede } \\
\text { or Twente, } \\
\text { remained } \\
\text { in the } \\
\text { region }\end{array}$ & $\begin{array}{l}\text { Established } \\
\text { in Enschede } \\
\text { or Twente, } \\
\text { moved to any } \\
\text { other region }\end{array}$ & $\begin{array}{l}\text { Established } \\
\text { in Enschede } \\
\text { or Twente, } \\
\text { moved to one } \\
\text { of the Top 5 } \\
\text { largest cities } \\
\text { in NL }\end{array}$ & $\begin{array}{l}\text { Established } \\
\text { other any } \\
\text { region and } \\
\text { remained } \\
\text { there }\end{array}$ & $\begin{array}{l}\text { Established } \\
\text { in any other } \\
\text { region, } \\
\text { moved to } \\
\text { Twente or } \\
\text { Enschede }\end{array}$ \\
\hline $\begin{array}{l}\text { Average } \\
\text { size the } \\
\text { year before } \\
\text { migration }\end{array}$ & N/A & 4.3 & 7.3 & N/A & 2.3 \\
\hline $\begin{array}{l}\text { Average } \\
\text { size in } 2017\end{array}$ & 8.2 & 14.2 & 32.7 & 11.2 & 7.3 \\
\hline
\end{tabular}


Issue no. $27 / 2018$

Table 6 shows that measured in number of workplaces, spin-off companies on average profit from migration. Spin-off companies staying in the region Twente grow slower than the ones established in other regions and the ones moving out from Twente, especially those spin-offs moving to the five largest agglomerations of The Netherlands. It must be noted that new recently established University of Twente spin-offs are more likely to start their operations in the region Twente than elsewhere in The Netherlands, meaning that the average company size of 8.2 in Twente is somewhat stronger influenced by the smaller size of recently established spin-offs. The average size of more "mature" spin-offs in Twente is likely to be a bit larger. Additional research is needed to identify how big this "starters" effect is. Still, even with that factor in mind, it is clear that spin-offs outside the region are on average larger in size and it appears as if a location within the region Twente may hinder company growth (also for companies migrating there from other regions). Another factor that has to be taken into consideration is the strong skewedness of the sizes of the spin-offs. A handful of large companies (almost all of them located outside the region Twente), count for most of the workplaces and do influence the average company size. The vast majority (93\%) of the spin-offs, both inside and outside the region Twente remain small (less than 20 employees). Just over $1 \%$ of all spin-offs have more than 100 employees. When looking at the average size of the spin-offs without these large $1 \%$ "outliers", undoubtedly the differences would be less big. With the current dataset, without knowing about the motives of migrating from the individual spin-offs, it is not possible to conclude whether migration to a different region caused the stronger growth of these companies, further research is needed to answer that question. 


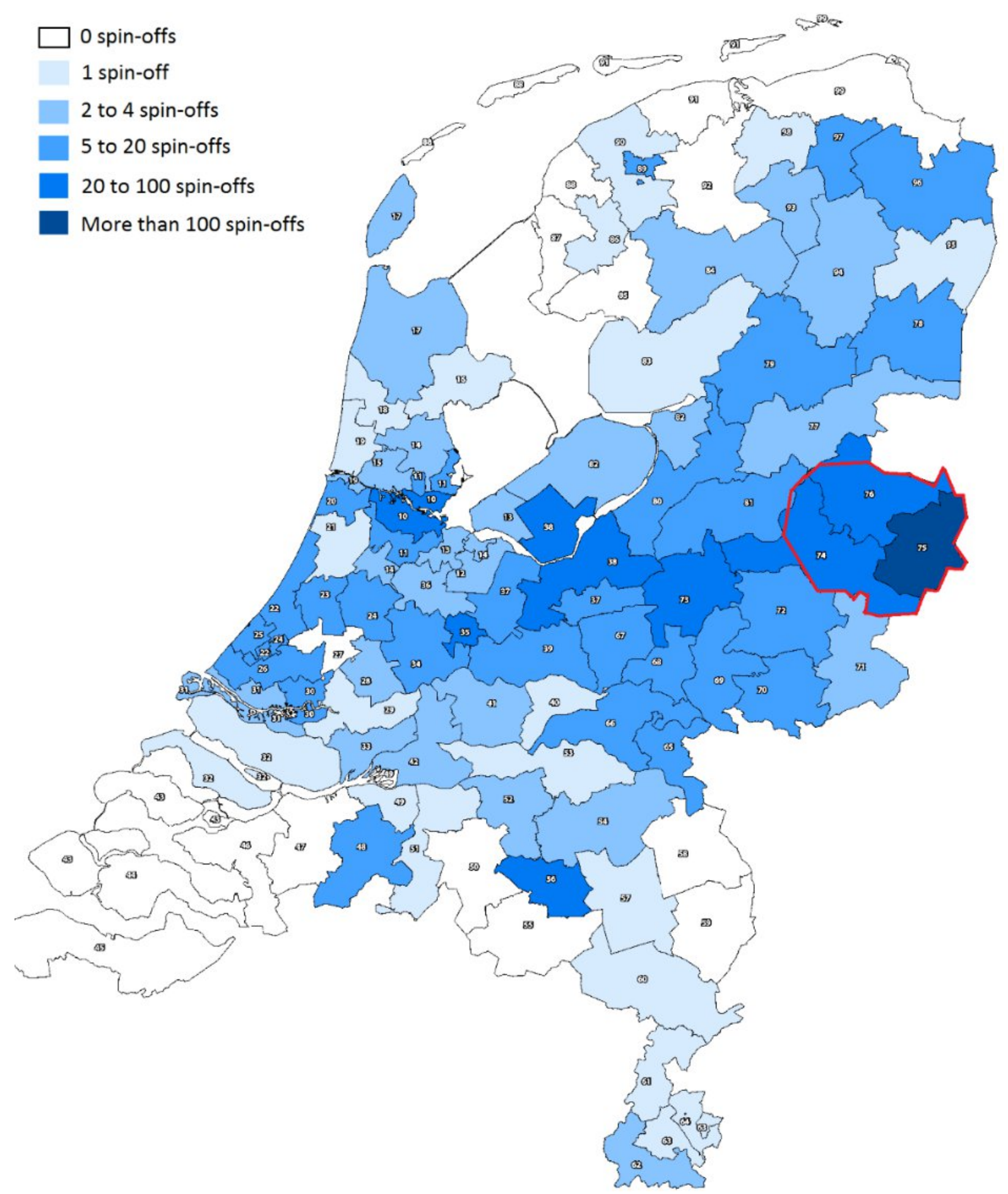

Figure 2: Location of University of Twente spin-offs as per 2017. The red encircled area represents the region Twente.

\section{Conclusions and discussion}

On the basis of the available data can be concluded that the majority of the spin-off companies do not move and remain in the region where they are originally established, 
similar to the findings of Van Wissen and Schutjens (2005). Even though this study does not involve any investigation into the specific motives of individual spin-off companies for their relocation, the most important motives mentioned by Pellenbarg (2005) may very well play a role, the search for "space to expand" and "business economic motives", in other words better business opportunities elsewhere. Even though most spin-offs are firmly rooted in the place where they are, there are migration movements to more core areas in the Netherlands, out of the more peripheral region Twente. This movement is especially visible when looking at the number of job places involved. Spin-offs moving to the five largest Dutch agglomerations (Amsterdam, Rotterdam, Den Haag, Utrecht and Eindhoven) grow faster than spin-offs that do not move. A possible explanation for this is that entrepreneurs searching a place within larger agglomerations may be more ambitious (Van der Meer et al., 2010). The average age of spin-offs when they migrate is for intra-regional migrations 9 years and inter-regional migrations 10 years, indicating that on average University of Twente spin-offs migrate after they leave the first start-up period behind them, consistent with the findings of Atzema et al. (2002) for companies in The Netherlands in general.

When looking at the spin-off companies in more detail, using the Pirnay et al. (2003) typology of four types of spin-offs, some interesting difference in spatial behaviour of the four different types becomes apparent. Type I spin-offs of the University of Twente, the ones with new patented technologies, tend to stay rather close to the parent university, or are attracted by it in case of being established elsewhere. This pattern is similar to the expectations of Roberts (1991) and can be explained by the knowledge spill-over theory which explains the attraction of these companies to the parent university (Acs et al., 2009), even if it is located in a more peripheral region with (potentially) limited access to high skilled labour and investment capital. For Type II spin-offs, the research-based ones, a similar pattern as for the Type I's is visible, although the attraction of the university seems to be slightly weaker. Type III spin-offs, the ones that got formal support from the university, seem to be the most firmly rooted in the region Twente, likely because of strong local networks, although the attractiveness of the Twente region for Type III spin-offs established in other regions is considerably lower. Twente has the lowest attraction as business location for Type IV spin-offs, the rest category consisting of all students and graduates who started their 
Issue no. $27 / 2018$

company less than five years after leaving the university and do not fit in one of the other categories. This category consists of most of the largest spin-off companies, which are not necessarily high-tech companies, reinforcing the ideas of Down (2010), Hughes (2010) and Harrison and Leitch (2010) that high-tech spin-offs usually stay small and play a mere supporting role in the regional economy. At the same time, there is also no sign of spin-off companies hurting in one way or the other the regional economy of Twente (Benneworth \& Hospers, 2007a), which leads to the conclusion that these companies have a beneficial effect. When looking at the average sizes of the different spin-off types (Table 2), there is little evidence that Type III and IV are on average "lifestyle companies" (Timmons \& Spinelli, 2008) or just "alternatives to the paid labour market" (Harrison \& Leitch, 2010). On the other hand, it is true that the percentage of sole-proprietors in these two spin-off categories is the highest, providing some evidence that in some cases these labels could be justified for Type III and IV spin-offs.

A previous study on spin-off locations of the Saxion University of Applied Sciences in Enschede has yielded similar results, larger spin-offs are usually located outside the region Twente, but also here the majority of spin-offs once established in the region Twente, stays within the region (Van der Meer et al., 2010). The conclusion can be made that, even though there is a net loss of numbers of spin-offs and workplaces through migration out of Enschede and the Twente region, these losses in both numbers of spin-offs and workplaces are relatively small, indicating that there is even in this post-industrial former textile producing region still a reasonable attractive business climate for most university spin-offs. If these remaining spin-off companies can cause a serious impact and change in the regional economy remains to be seen, this is a different discussion of which some of the ideas have been mentioned earlier in this paper. In any case, for university administrators, the message to take away from this study is that investment in spin-offs in terms of support in training, providing with finance and/or introduction to different regional networks can help to keep spin-offs in the region close to the university: This is visible in the higher spin-off retention percentages for the Type I to III spin-offs (See table 6). Type IV spin-offs of which the entrepreneurs have been only implicitly supported, in terms of one or more courses in entrepreneurship during their study and maybe got inspired by some of the entrepreneurs of other spin-offs, 
Issue no. $27 / 2018$

have a higher chance of not starting their business in Twente in the first place or are more likely than the other spin-off types to move their company out of this region.

This study has - with the (in some cases) inaccuracies - of the Dutch trade register, painted a picture of the location patterns and migration of spin-off companies of the University of Twente. Further research is required to find out why some of the spin-off companies decide to leave the region Twente. The motives for spin-off migration are still sorely missing, despite earlier work on this issue by Pellenbarg about migration motives in general in The Netherlands. Also, further research is needed to better understand the effects of business clusters and regional specialization on the attractiveness of non-core regions for spin-off companies, building further on the work of Baumgartner et al. (2013).

\section{References}

- ACS, Z. J., BRAUNERHJELM, P., AUdRETSCH, D. B., \& CARLSSON, B. (2009). The knowledge spillover theory of entrepreneurship. Small Business Economics, 32(1), 15-30. doi:10.1007/s11187-008-9157-3

- ARBO, P., \& BENNEWORTH, P. (2007). Understanding the Regional Contribution of Higher Education Institutions: A Literature Review. OECD Education Working Papers, No. 9. OECD Publishing (NJ1).

- ARMSTRONG, P. (2001). Science, enterprise and profit: ideology in the knowledgedriven economy. Economy and Society, 30(4), 524-552. doi:10.1080/03085140120089081

- AtZemA, O., LAMbooy, J., RIETBERGEN, T. V., \& WEVER, E. (2002). Ruimtelijke Economische Dynamiek. Kijk op bedrijfslocatie en regionale ontwikkeling.

- AUDRETSCH, D. B., \& LEHMANN, E. E. (2005). Does the knowledge spillover theory of entrepreneurship hold for regions? Research Policy, 34(8), 1191-1202. doi:10.1016/j.respol.2005.03.012

- AUDRETSCH, D. B., \& LEHMANN, E. E. (2017). The Knowledge Spillover Theory of Entrepreneurship and the Strategic Management of Places. In G. Ahmetoglu, T. 
Issue no. $27 / 2018$

Chamorro- Premuzic, B. Klinger, \& T. Karcisky (Eds.), The Wiley Handbook of Entrepreneurship. London: Wiley\&Sons.

- BAUMGARTNER, D., PÜTZ, M., \& SEIDL, I. (2013). What Kind of Entrepreneurship Drives Regional Development in European Non-core Regions? A Literature Review on Empirical Entrepreneurship Research. European Planning Studies, 21(8), 1095-1127. doi:10.1080/09654313.2012.722937

- BAZEN, J. C., \& BIJLEVELD, P. C. (2012). Re-structuring of a Dutch mono-industrial region; example of Twente. In O. D. Ugolnikova (Ed.), Restructuring of mono-industrial cities. St. Petersburg: St. Petersburg State University of Service and Economics.

- BENNEWORTH, P., \& CHARLES, D. (2005). University spin-off policies and economic development in less successful regions: Learning from two decades of policy practice. European Planning Studies, 13(4), 537-557. doi:10.1080/09654310500107175

- BENNEWORTH, P., \& HOSPERS, G. J. (2007a). The new economic geography of old industrial regions: universities as global-local pipelines. Environment and Planning C: Government and Policy, 25(6), 779-802. doi:10.1068/c0620

- BENNEWORTH, P., \& HOSPERS, G. J. (2007b). Urban competitiveness in the knowledge economy: Universities as new planning animateurs. Progress in Planning, 67, 105-197. doi:10.1016/j.progress.2007.02.003

- BIRD, B., \& SCHJOEDT, L. (2009). Entrepreneurial Behavior: Its Nature, Scope, Recent Research, and Agenda for Future Research. In A. L. Carsrud \& M. Brännback (Eds.), Understanding the Entrepreneurial Mind: Opening the Black Box (pp. 327-358). New York, NY: Springer New York.

- BODE, E. (2004). Spatial pattern of localized R\&D spillovers. Journal of Economic Geography, 4(1), 43-64. doi:10.1093/jeg/4.1.43

- BOOT, J. A. P. G. (1935). De Twentsche katoennijverheid 1830-1873: H.J. Paris.

- Brouwer, A. E., MARIOTTI, I., \& VAN OMMEREN, J. N. (2004). The firm relocation decision: An empirical investigation. The Annals of Regional Science, 38(2), 335-347. 
- CARSRUD, A., \& BRANNBACK, M. (2011). Entrepreneurial Motivations: What Do We Still Need to Know? Journal of Small Business Management, 49(1), 9-26. doi:10.1111/j.1540-627X.2010.00312.X

- ClARYSSE, B., Wright, M., LOCKETT, A., VAN DE VELDE, E., \& VOHORA, A. (2005). Spinning out new ventures: a typology of incubation strategies from European research institutions. Journal of Business Venturing, 20(2), 183-216. doi:https://doi.org/10.1016/j.jbusvent.2003.12.004

- COCORULlO, A. (2017, 30-31 March 2017). University Fourth Mission. Spin-offs and academic entrepreneurship: a theoretical review through the variety of definitions. Paper presented at the EURASHE 27th Annual Conference, Le Havre.

- DAVID, A., \& COENEN, F. (2014). Alumni Networks - An Untapped Potential to Gain and Retain Highly-Skilled Workers? Higher Education Studies, 4(5), 1 - 17. doi:10.5539/hes.v4n5p1

- DE BOK, M. (2004). Explaining the location decision of moving firms using their mobility profile and the accessibility of locations.

- DI GREGORIO, D., \& SHANE, S. (2003). Why do some universities generate more start-ups than others? Research Policy, 32(2), 209-227. doi:https://doi.org/10.1016/S0048-7333(02)00097-5

- DJOKOVIC, D., \& SOUITARIS, V. (2008). Spinouts from academic institutions: a literature review with suggestions for further research. Technology Transfer, 33, 225-247. doi:0.1007/s10961-006-9000-4

- DOWN, S. (2010). Enterprise, Entrepreneurship and Small Business. London: SAGE Publications.

- DUMA, F. (2014). Promoting the entrepreneurship education in Europe. On-line Journal Modelling the New Europe (10), 67-79.

- ETZKOWITZ, H., \& LEYDESDORFF, L. (2000). The dynamics of innovation: from National Systems and "Mode 2" to a Triple Helix of university-industry-government relations. Research Policy, 29(2), 109-123. doi:10.1016/s0048-7333(99)00055-4 
- EtzKOWITZ, H., WEBSter, A., GEBhARDT, C., \& TERRA, B. R. C. (2000). The future of the university and the university of the future: evolution of ivory tower to entrepreneurial paradigm. Research Policy, 29(2), 313-330. doi:10.1016/s00487333(99)00069-4

- FERNÁNDEZ-ALLES, M., CAMELO-ORDAZ, C., \& FRANCO-LEAL, N. (2015). Key resources and actors for the evolution of academic spin-offs. Technology Transfer, 40, 976-1002. doi:10.1007/s10961-014-9387-2

- FLORIDA, R. (2002). The rise of the creative class. New York: Basic Books.

- FLORIDA, R. (2008). Who's your city? New York: Basic Books.

- GODDARD, J. B., \& CHATTERTON, P. (2003). The response of universities to regional needs. Economic Geography of Higher Education: Knowledge, Infrastructure and Learning Regions, Routledge, London, 19-41.

- GODDARD, J. B., ROBERTSON, D., \& VALLANCE, P. (2012). Universities, Technology and Innovation Centres and regional development: the case of the North-East of England. Cambridge Journal of Economics, 36, 609-627. doi:10.1093/cje/bes005

- GRABHER, G. (1993). The embedded firm : on the socioeconomics of industrial networks. London: Routledge.

- Guerrero, M., URBAnO, D., CUNningham, J., \& ORGAN, D. (2014). Entrepreneurial universities in two European regions: a case study comparison. Technology Transfer, 39, 415-434. doi:10.1007/s10961-012-9287-2

- HARRISON, R. T., \& LEITCH, C. (2010). Voodoo Institution or Entrepreneurial University? Spin-off Companies, the Entrepreneurial System and Regional Development in the UK. Regional Studies, 44(9), 1241-1262. doi:10.1080/00343400903167912

- HOSPERS, G. J. (2015). Industrie, innovatie en regionale ontwikkeling. In B. de Pater \& L. J. Paul (Eds.), Europa: Een nieuwe geografie (pp. 153-176). Utrecht: Perspectief Uitgevers.

- HUGHES, A. (2010). Innovation policy as cargo cult: myth and reality in knowledge-led productivity growth The Innovation for Development Report 2009-2010 (pp. 101-117): Springer. 
Issue no. $27 / 2018$

- Institute for Work and Technology Westfälische Hochschule. (2014). Brain Flow: Attracting and Retaining Talent in European Border Regions Retrieved from Gelsenkirchen:

http://www.brain-

flow.eu/export/sites/brainflow/downloads/Brain_Flow_final_report.pdf

- KOOPMAN, R. G. M. (2013). Coaching and mentoring entrepreneurs-more definitions won't work. Paper presented at the 27nd RENT.

- KRUEGER, N. (2009). Entrepreneurial Intentions are Dead: Long Live Entrepreneurial Intentions. 51-72. doi:10.1007/978-1-4419-0443-0_4

- KRUEGER, N., REILly, M. D., \& CARSRUD, A. L. (2000). Competing models of entrepreneurial intentions. Journal of Business Venturing, 15(5-6), 411-432. doi:10.1016/s0883-9026(98)00033-0

- LAZZERETTI, L., \& TAVOLETTI, E. (2005). Higher Education Excellence and Local Economic Development: The Case of the Entrepreneurial University of Twente. European Planning Studies, 13(3), 475-493. doi:10.1080/09654310500089779

- LUTHJE, C., \& FRANKE, N. (2003). The 'making' of an entrepreneur: testing a model of entrepreneurial intent among engineering students at MIT. $R \& D$ Management, 33(2), 135-147. doi:10.1111/1467-9310.00288

- MÄKELÄ, M. M., \& MAULA, M. V. (2005). Cross-border venture capital and new venture internationalization: An isomorphism perspective. Venture Capital, 7(3), 227257.

- MASKELL, P., \& MALMBERG, A. (1999). The competitiveness of firms and regions, 'ubiquitification' and the importance of localized learning. European Urban and Regional Studies, 6(1).

- MÜLlER, K. (2010). Academic spin-off's transfer speed-Analyzing the time from leaving university to venture. Research Policy, 39, 189-199. doi:10.1016/j.respol.2009.12.001

- $\quad$ Mustar, P., RENAUlt, M., COlOMbO, M., PIVA, E., FONTES, M., LOCKETT, A., . . MORAY, N. (2006). Conceptualising the heterogeneity of research-based spin- 
Issue no. $27 / 2018$

offs: A multi-dimensional taxonomy. Research Policy, 35, 289-308. doi:10.1016/j.respol.2005.11.001

- O'SHEA, R. P., ALlEN, T. J., CHEVALIER, A., \& ROCHE, F. (2005). Entrepreneurial orientation, technology transfer and spinoff performance of US universities. Research Policy, 34(7), 994-1009. doi:10.1016/j.respol.2005.05.011

- PARMENTOLA, A., \& FERRETTI, M. (2018). Stages and trigger factors in the development of academic spin-offs: An explorative study in southern Italy. European Journal of Innovation Management, 21(3), 478-500. doi:10.1108/EJIM-11-2017-0159

- PEllenBARG, P. H. (2005). Firm migration in the Netherlands. Paper presented at the 45th Congress of the European Regional Science Association: "Land Use and Water Management in a Sustainable Network Society", 23-27 August 200, Amsterdam. http://hdl.handle.net/10419/117632

- PIRnAY, F., SURlEMONT, B., \& NLEMVO, F. (2003). Toward a Typology of University Spin-offs. Small Business Economics, 21(4), 355-369. doi:10.1023/a:1026167105153

- PLANT, R. (2007). An empirical analysis: Venture Capital clusters and firm migration. Journal of Developmental Entrepreneurship, 12(2), 139-163.

- PORTER, M. E. (1990). The Competitive Advantage of Nations. New York: Free press.

- PUGH, R. (2017). Universities and economic development in lagging regions: 'triple helix' policy in Wales. Regional Studies, 51(7), 982-993. doi:10.1080/00343404.2016.1171306

- ROBERTS, E. B. (1991). Entrepreneurs in high technology: Lessons from MIT and beyond: Oxford University Press.

- ROMER, P. M. (1990). ENDOGENOUS TECHNOLOGICAL-CHANGE. Journal of Political Economy, 98(5), S71-S102. doi:10.1086/261725

- ROThAERMEL, F. T., AGUNG, S. D., \& JIANG, L. (2007). University entrepreneurship: a taxonomy of the literature. Industrial and Corporate Change, 16(4), 691-791. doi:10.1093/icc/dtm023 
- SARASVATHY, S. D. (2001). Causation and effectuation: Toward a theoretical shift from economic inevitability to entrepreneurial contingency. Academy of Management Review, 26(2), 243-263. doi:10.2307/259121

- SARASVATHY, S. D., \& VENKATARAMAN, S. (2011). Entrepreneurship as Method: Open Questions for an Entrepreneurial Future. Entrepreneurship Theory and Practice, 35(1), 113-135. doi:10.1111/j.1540-6520.2010.00425.x

- SHANE, S. A. (2004). Academic entrepreneurship: University spinoffs and wealth creation: Edward Elgar Publishing.

- SHINNAR, R. S., GIACOMIN, O., \& JANSSEN, F. (2012). Entrepreneurial Perceptions and Intentions: The Role of Gender and Culture. Entrepreneurship Theory and Practice, 36(3), 465-493. doi:10.1111/j.1540-6520.2012.00509.x

- TERLUIN, I. J. (2003). Differences in economic development in rural regions of advanced countries: an overview and critical analysis of theories. Journal of Rural Studies, 19(3), 327-344. doi:10.1016/s0743-0167(02)00071-2

- TIMMONS, J., \& SPINELLI, S. (2008). New Venture Creation: McGraw-Hill Publishing.

- TÖDTLING, F., \& TRIPPL, M. (2005). One size fits all?: Towards a differentiated regional innovation policy approach. Research Policy, 34(8), 1203-1219. doi:https://doi.org/10.1016/j.respol.2005.01.018

- VAN DER MEER, R., VAN DER MEER, H., \& BIJLEVELD, P. (2010). Prospering outside the region?: spatial patterns of spin offs universities of applied science. Enschede. https://proceedings.utwente.n1/75/1/vandermeer.pdf

- VAN DER SIJDE, P., \& VAN TILBURG, J. (2000). Support of university spin-off companies. The International Journal of Entrepreneurship and Innovation, 1(1), 13-21.

- VAN DER SiJde, P., VOGElaAR, G., HOOGEVEEN, A., LIGTENBERG, H., \& VAN VELZEN, M. (2002). Attracting high-tech companies: the case of the University of Twente and its region. Industry and Higher Education, 16(2), 97-104.

- VAN DiJK, J., \& PEllenbarg, P. H. (2000). Firm relocation decisions in The Netherlands: An ordered logit approach. Papers in Regional Science, 79(2), 191-219. 
- VAN TIlbURG, J. J., \& VAN DER SIJDE, P. (1998). The UNISPIN model. A systematic approach for university spin-off development Proceedings of the 6th Annual International Conference 'High Technology Small Firms' (pp. 661 - 677).

- VAN WISSEN, L. J., \& SCHUTJENS, V. (2005). Geographical scale and the role of firm migration in spatial economic dynamics.

- WAllersteIN, I. M. (1974). The Modern World-System I: Capitalist Agriculture and the Origins of the European World-Economy in the Sixteenth Century. Los Angeles: University of California Press.

- WEVER, E., \& STAM, E. (1999). Clusters of high technology SMEs: The Dutch case. Regional Studies, 33(4), 391-400. doi:10.1080/713693556 